\title{
HOW EFFICIENT ARE PENSION FUND MANAGERS IN CHILE?*
}

\author{
Armando Barrientos
}

\author{
Aziz Boussofiane ${ }^{* *}$
}

\begin{abstract}
The paper measures and evaluates technical efficiency among pension fund managers in Chile. Recent pension reform has established pension fund management market in nine countries in Latin America. The new pension providers compete for affiliates on the basis of fees, rates of return, and quality of service, and are subject to extensive regulation. Applying data envelopment analysis to data from Chile 1982-1999, the paper examines issues of efficiency, competition, and regulation. The analysis concludes that pension fund managers operate below the estimated "efficiency frontier", and there is no evidence of a sustained upward trend in technical efficiency over time.
\end{abstract}

Key words: pension reform, pension fund managers, efficiency, competition, regulation

JEL Code: H55

\section{QUÃO EFICIENTES SÃO OS ADMINISTRADORES \\ DE FUNDOS DE PENSÃO NO CHILE?}

RESUMO Este artigo se propõe a avaliar e medir a eficiência técnica dos administradores de fundos de previdência privada no Chile. A recente reforma sofrida pela previdência deu lugar a um mercado de gestão de fundos de aposentadoria em nove países da América Latina. Esses novos gestores de fundos de pensão competem por investidores através do custo de suas tarifas, dos índices de rendimento oferecidos e da qualidade do serviço prestado, estando sujeitos a uma regulamentação rigorosa. Aplicando a análise por envoltória de dados (DEA) aos dados obtidos para o Chile

* Artigo recebido em 6 de julho de 2004 e aprovado em 13 de abril de 2005.

** Professor do Institute for Development Policy and Management, University of Manchester, Oxford Road. IDPM, University of Manchester, Oxford Road, Manchester M13 9 QH, UK, e-mail armando.barrientos@manchester.ac.uk

*** Professor da University of Hertfordshire Business School, Mangrove Road, e-mail a.e.a.boussofiane @herts.ac.uk. 
entre 1982 e 1999, examinamos aqui as questões de eficiência, competitividade e regulamentação. Nossa análise conclui que os administradores de fundos de previdência privada operam abaixo do nível de eficiência desejado, e não há previsão de que venha a ocorrer nenhuma melhora consistente na eficiência técnica desses fundos num futuro próximo.

Palavras-chave: reforma da previdência; administradores de fundos de pensão; eficiência; competitividade; regulamentação

Código JEL: H55 


\section{INTRODUCTION}

The spread of pension reform in Latin America in the 1990s has replaced unfunded semipublic pension schemes with individual retirement saving plans managed by private pension fund managers (Barrientos, 1998; MesaLago and Bertranou, 1998; Queisser, 1998b). ${ }^{1}$ The establishment of a pension fund management market is one of the most consequential elements of the reform, with implications for financial and insurance markets, and for the welfare of pensioners (Barrientos, 1999). ${ }^{2}$ Pension fund managers perform key functions. They collect workers' contributions into a pension fund, invest this fund in a range of financial assets, provide disability and survivor insurance, arrange pension benefits for those retiring, and provide a range of supporting services. To an important extent, the success or failure of pension reform hinges on whether pension fund managers are effective as pension providers. However, research on the performance of pension fund managers in the region is scant, and the efficiency of pension fund managers has not been addressed explicitly. This paper applies data envelopment techniques to measure and evaluate the technical efficiency of pension fund managers, and to assess the structure and performance of the pension fund management market in Chile.

Under the 1981 pension reform in Chile, dependent workers are required to contribute a fraction of their earnings to an individual retirement account with a pension fund manager, or Administradoras de Fondos de Pensiones (AFP). These corporations are set up with the exclusive purpose of managing retirement accounts, and are regulated by the Superintendencia de Administradoras de Fondos de Pensiones (SAFP). ${ }^{3}$ The designers of pension reform in Chile, and elsewhere in Latin America, planned for pension fund managers to operate in a competitive environment, albeit subject to detailed supervision and regulation. Competition extends to fees, rates of return, and quality of service, with affiliates able to transfer their accounts from one pension fund manager to another in search of a better deal. The regulation of fund managers is extensive, and covers products, fees, investment portfolios, rates of return, and standards of service and probity. Competition is held to be instrumental to the efficiency of the market, while regulation addresses information asymmetries and provides a prudential safety net. ${ }^{4}$ 
The literature on the emerging pension fund management market in Latin America is limited. Some contributions address market design issues (James and Vittas, 1996; James, Ferrier et al., 1998); regulation (Queisser, 1998a; Vittas, 1998); fees (Paredes, 2000; James, Smalhout et al., 2001); finance (Yermo, 2000); and issues of market efficiency and competition, which have been covered in evaluations of pension reform as a whole in Chile and Latin America (Diamond, 1993; Edwards, 1996; Barrientos, 1998; Mesa-Lago and Bertranou, 1998; Queisser, 1998b; Schmidt-Hebbel, 1999; Mesa-Lago, 2002). Few contributions focus on the operation of the pension fund management market (Superintendencia de Administradoras de Fondos de Jubilaciones y Pensiones, 1996; Bertín, 1997; Barrientos, 1998; James, Ferrier et al., 1998; Queisser, 1998b; Sinha, Martínez et al., 1998; Barrientos, 1999), and the efficiency of pension fund managers has not been tackled directly, despite the key role of pension fund managers in the reformed pension environment.

This paper examines the efficiency of pension fund managers. It uses data envelopment analysis to measure and evaluate the technical efficiency of pension fund managers in Chile over the period from 1982 to 1999. We focuse is the country with on Chile because it has the longest experience with pension reform, and because it provided a model of the structure of the market other countries have followed closely. The estimated measures of technical efficiency provide evidence on the performance of the pension fund management market over time, the limits on competition, and the effects of fees regulation on the market strategies of the pension fund managers. We found that the potential technical efficiency gains in the market are significant, and that there is no evidence of a sustained upward trend in technical efficiency over time.

The paper is organized as follows: section one outlines and discusses the performance of pension fund managers in Chile to date, identifying key efficiency, competition, and regulation issues. Section Two introduces Data Envelopment Analysis (DEA) and justifies its applicability to the pension fund management market; section three reports on the estimated technical efficiency measures and discusses their implications for the evaluation of the structure and performance of the market; a final section summarizes the main conclusions. 


\section{THE PERFORMANCE OF PENSION FUND MANAGERS IN CHILE: EFFICIENCY AND REGULATION ISSUES}

This section examines the performance of fund managers in Chile and identifies key efficiency, competition, and regulation issues.

\section{(a) Competition in the pension fund management market}

Table 1 below shows key performance indicators for the pension fund management market in Chile. These indicators provide conflictive signals on the extent of competition in the market.

The number of pension fund managers oscillated around 12 in the period up to the early 1990 s, when a relaxation in entry regulations ${ }^{5}$ led to a rise in the number of pension fund managers to 22 in 1993. A subsequent consolidation in response to strong market pressure and adverse investment returns resulted in only eight fund managers remaining in the market. Entry requirements for pension fund managers include a minimum capital requirement, a reserve of 1 percent of the pension fund, ${ }^{6}$ and "fit and proper" licensing by the SAFP (Yermo, 2000). The evolution in the number of pension fund managers suggests that market entry is not too difficult, and that aggressive marketing from new entrants can secure some market share initially.

The market is very concentrated. The three largest pension fund managers accounted for 63 percent of active contributors in 1982, their share rising to 67 percent in 1990, and to 75 percent in 1999. Market concentration can be explained by economies of scale in the management of retirement accounts. ${ }^{7}$ Miranda (1994) measured economies of scale in the Chilean

Table 1: Key Indicators of the Pension Fund Management Market in Chile

\begin{tabular}{lccccc}
\hline Indicator & 1982 & 1985 & 1990 & 1995 & 1999 \\
\hline Number of AFPs & 12 & 11 & 14 & 16 & 8 \\
\hline Largest 3 share (\% contributors) & 0.63 & 0.62 & 0.67 & 0.67 & 0.75 \\
\hline Affiliates (m.) & 1.44 & 2.28 & 3.73 & 5.32 & 6.10 \\
\hline Contributors (m.) & 1.06 & 1.32 & 1.96 & 2.48 & 2.69 \\
\hline Transfers (m.) & & 0.18 & 0.31 & 1.32 & 0.48 \\
\hline Sales personnel (,000s) & 1.88 & 2.41 & 3.44 & 15.43 & \\
\hline Annual rate of return (\%) & 12.8 & 13.4 & 15.6 & -2.5 & 16.3 \\
\hline
\end{tabular}

Data Source: Barrientos (1998), Superintendencia de Administradoras de Fondos de Pensiones (several issues). 
pension fund management market. Using data from a panel of pension fund managers for the period from 1982 to 1993, he estimated that, for every 1 percent rise in the number of active contributors, operational costs rise in the range of 0.6 to 0.8 percent. James et al. find substantial economies of size in asset management, and estimate, in the case of Chile, that scale economies are fully exploited when a pension fund manager "has three million affiliates and [assets of] US\$ 15 billion — half the current Chilean market" (2001, p.267).

The design of pension plans in Chile encourages an individual choice of pension fund manager, as a means of ensuring that competitive forces prevail. In order to facilitate this choice, pension products are standard, fees are uniform for all affiliates to a single AFP, and secondary products are closely regulated. Pension plan participants in Chile are expected to compare rates of return, fees and service quality between the different pension fund managers, and to transfer their accounts to the one with the best deal.

The number of transfers would seem to indicate a healthy measure of competition, but the variation in the number of transfers over time is largely explained by regulatory changes. Initially, participants wishing to transfer to another AFP had to make a request in person at a branch office, but in February 1988, the regulations were relaxed to allow participants to request a transfer through a signed form. This led to a rapid rise in transfers, further encouraged in 1992 by the aggressive marketing efforts of new market entrants. ${ }^{8}$ In 1987, there were 181,048 transfers, equivalent to 10 percent of active contributors, but, by 1995, the number, of transfers had skyrocketed to 1.32 million transfers, equivalent to 53 percent of active contributors. The reinstatement of the requirement to apply for the transfer in person at a branch office reduced transfers to 0.48 million in 1999, equivalent to 18 percent of active contributors.

It is questionable whether a high level of transfers is an indicator of healthy competition. Abuhadba (1994) studied the determinants of transfers using a panel of monthly cross sections of individual transfers between pension fund managers for the period from April 1992 to June 1993. He regressed transfers on a range of variables including rates of return, fees and sales personnel. He found rates of return and fees had only a small impact on transfer behaviour, and returns over a longer period had little or no effect. The dominant factor was found to be the number of sales personnel 
employed by fund managers. Pension plan participants appear to be fairly insensitive to differences in performance indicators between pension fund managers. This may be due to the high information costs required to make pension plan choice decisions, ${ }^{9}$ or to the fact that these performance differentials between pension fund managers are too small to matter. The conclusion is that competition is limited in the pension fund management market.

\section{(b) Trends in the cost structure of pension fund managers}

Information on the performance and efficiency of pension fund managers can also be extracted from the examination of their cost structure. Figure 1 shows the evolution of operational costs per active contributor. These include costs of personnel (in administration, sales and management), as well as those associated with administration, computing and marketing. To facilitate comparison across time, the series are reported in constant US\$ and per active contributor. ${ }^{10}$ Total operational costs per active contributor decline from 1982 to 1987, reflecting the spread of large setup costs across a rising number of contributors. In 1987, pension fund managers began to reinsure against disability and survivor liabilities, which is reflected in a step change in their cost structure. Operational costs decline steadily from 1988 to 1992 , but they show a rising trend after 1992, accelerating later on due to the impact of new entrants. The introduction of stricter regulations on transfers in 1998 stems the rise in costs. Overall operational costs show a sustained increase over time. This runs counter expectations that competition would force pension fund managers to reduce costs. ${ }^{11}$

When operational costs are disaggregated into their different components, it becomes apparent that the rise in operational costs after 1992 is explained by the rapid rise in sales personnel costs. New entrants relied upon sales personnel to capture market share by attracting contributors from existing pension fund managers, who in turn reacted by expanding their sales force to protect their market share. From 1994 onwards, pension fund managers employ more personnel in sales than in administration, and the salary costs of sales personnel are greater than the salary costs of administrative and management personnel combined. The sustained increase in operational costs over time, and especially sales costs, is not consistent with improvements in efficiency. 
Figure 1: Operational costs per contributor (USS December 1998)

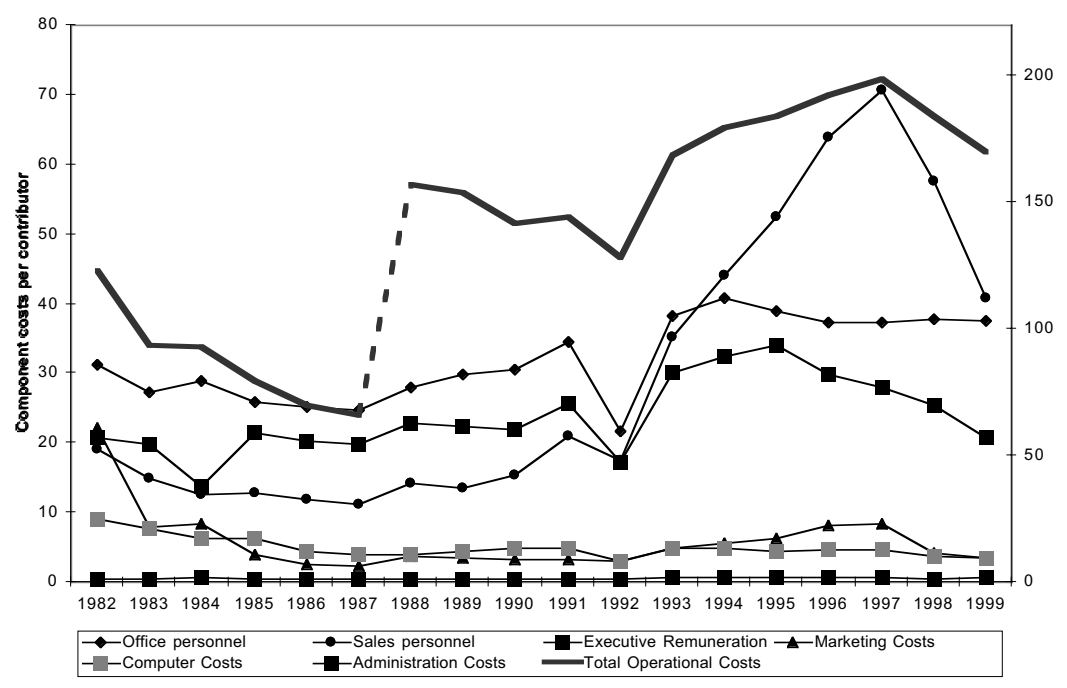

(c) Fee structure, regulation, and market strategies

Fee income is the main source of revenue for the pension fund managers. ${ }^{12}$ It would be expected that the steady rise in their operational costs would come up against restrictions on the revenue side, but regulation effectively lifts these potential restrictions. The regulatory framework defines what services can attract fees, and the type of fees (fixed or proportional), but pension fund managers are free to decide whether or not to implement these charges, and to what degree. Fees can be levied on fund management, retirement account deposits, transfers, deposits and withdrawals from voluntary savings accounts, withdrawals from voluntary severance accounts, and pension benefit payments.

Fund managers are, as a result, free to set a fee structure that is out of line with their cost structure, but which maximises their market advantage vis a vis other financial institutions (Barrientos, 1998). Pension fund managers have been reluctant to use the full range of permitted fees. In order to forestall retaliation measures, they are reluctant to charge fees for transfers. In order to compete more effectively with insurance companies offering pension annuities, they have been slow to charge for the management of retirement accounts. ${ }^{13}$ They have never charged fees on voluntary savings and on 
severance savings accounts, in order to maximise their attractiveness relative to savings accounts offered by banks. As a result, the full operational costs of fund managers fall upon regular contributors to individual retirement accounts mainly through earnings — related variable fees. ${ }^{14}$ There is a significant misalignment of their revenue and cost structures, with adverse effects on competition and performance.

Two broad market strategies have evolved in the pension fund management market. Some pension fund managers have sought to maximise market share in order to exploit economies of size in the market. At the other end of the spectrum, some pension fund managers have chosen to remain relatively small, and to focus their marketing efforts on finding and retaining high earners. This is made easier where affiliates have a strong allegiance nurtured by trade unions and other organizations. Those managers rely on a misalignment of costs and revenues. Mean operational costs are likely to decline in contributory earnings, but fee income rises directly with contributory earnings. Smaller pension fund managers can therefore absorb high operational costs by focusing on high earners, and a selective marketing strategy allows them to survive and prosper. A segmentation in market strategy could well be detrimental to competition, as well as to improvement in market efficiency.

In sum, standard indicators of performance in the pension fund management market help identify a number of issues regarding efficiency, competition, and regulation in the market. The following sections seek to ellaborate on these.

\section{EFFICIENCY MEASUREMENT AND DATA}

Data Envelopment Analysis (DEA) is a nonparametric technique which has been used to compare the technical efficiency of relatively homogeneous sets of production units. It was initially developed to compare the technical efficiency of public sector and not-for-profit production units (Charnes, Cooper et al., 1978), but, more recently, it has been applied successfully to the financial sector (Fields and Murphy, 1989; Ferrier and Lovell, 1990; Fields, Murphy et al., 1993; Nasser Katib and Matthews, 1999). It is therefore appropriate to the task of analysing the technical efficiency of pension 
fund managers in Latin America, especially as these are restricted by regulation to provide standard services, and to apply similar fees and charges to their affiliates.

\section{(a) CCR and BCC models}

In DEA, efficiency is defined as the ratio between a weighted sum of outputs and a weighted sum of inputs, where sets of weights for each of the observed production units are found by solving the following model proposed by Charnes, Cooper and Rhodes (1978), referred to as the CCR model (Boussofiane and Dyson, 1991):

$$
\operatorname{Max} h_{0}=\frac{\sum_{r=1}^{t} u_{r} y_{r j 0}}{\sum_{i=1}^{m} v_{i} x_{i j 0}}
$$

subject to:

$$
\frac{\sum_{r=1}^{t} u_{r} y_{r j 0}}{\sum^{m} v_{i} x_{i j 0}} \leq 1, \quad j=1, \ldots \ldots \ldots, n ; u_{r}, v_{i}>\varepsilon ; \forall_{r} \text { and } i
$$

where $n$ indexes units, $t$ indexes outputs, $m$ indexes inputs, and

$y_{r j}=$ amount of output $r$ from unit $j$,

$x_{i j}=$ amount of input $i$ to unit $j$.

$u_{r}=$ the weight given to output $r$,

$v_{i}=$ the weight given to input $i$,

$\varepsilon=$ a small positive number.

In this model, the efficiency of unit $j_{0}$ is maximised subject to the efficiencies of all units in the set, having an upper bound of 1 . The weights are treated as unknowns, assumed to be nonnegative, and will be chosen to maximise the efficiency of unit $j_{0}$. The unit observed is relatively efficient if the efficiency measure $h_{0}$ equals 1 , and inefficient if less than 1 . The efficiency of all other observed units is then measured in turn.

This model can be converted to a linear form, in order that linear programming can be applied, as in: 


$$
h_{0}=\operatorname{Max} \sum_{r=1}^{t} u_{r} y_{r j 0}
$$

subject to:

$$
\begin{aligned}
& \sum_{r=1}^{t} v_{i} x_{i j 0}=100, \\
& \sum_{r=1}^{t} u_{r} y_{r_{j}}-\sum_{i=1}^{m} v_{i} x_{i j} \leq 0 \quad j=1, \ldots \ldots ., n, \\
& -u_{r} \leq-\underline{\varepsilon}, r=1, \ldots, t, v_{i} \leq-\underline{\varepsilon}, i=1, \ldots, m .
\end{aligned}
$$

With this linearization, the denominator has been set to a constant (arbitrarily set at 100), and the numerator is maximised for each unit in turn. Alternatively, the dual can be solved:

$$
\operatorname{Min} 100 Z_{0}-\varepsilon \sum_{r=1}^{t} s_{r}^{+}-\varepsilon \sum_{i=1}^{m} s_{i}^{-}
$$

subject to:

$$
\begin{aligned}
& x_{i j 0}=Z_{0}-s_{i}^{-}-\sum_{j=1}^{n} x_{i j} \lambda_{j}=0, i=1, \ldots, m, \\
& -s_{r}^{+}+\sum_{j=1}^{n} x_{r j} \lambda_{j}=y_{r j 0}, r=1, \ldots, t, \\
& \lambda_{j}, s_{i}^{-}, s_{r}^{+} \geq 0 \quad \forall j, r \text { and } i, Z_{0} \text { unconstrained }
\end{aligned}
$$

Estimation of (3) generates an efficiency score for each of the units observed relative to all the others, which can be interpreted as an "efficient production frontier". The aggregate efficiency estimated for a unit equals the product of its pure technical and scale efficiency. An alternative model was provided by Banker, Charnes and Cooper (Banker, Charnes et al., 1984), who extend the CCR model to assess pure technical and scale efficiencies of units. Their model takes account of the effects of returns to scale within the units observed and identifies the most productive scale size for each unit. It has the additional restriction that the sum of the multipliers $l_{j}$ should add to 1 . The BCC model can be written as: 


$$
\operatorname{Min} h-\varepsilon\left[\sum_{i=1}^{m} s_{i}^{+}+\sum_{r=1}^{t} s_{r}^{-}\right]
$$

subject to:

$$
\begin{aligned}
& h x_{r j 0}-\sum_{i j}^{n} x_{i j} \lambda_{j}-s_{r}^{+}=0, i=1, \ldots, m, \\
& \sum_{j=1}^{n} y_{r j} \lambda_{j}-s_{r}^{+}=y_{r 0}, r=1, \ldots t, \\
& \sum_{j=1}^{n} y_{r j} \lambda_{j}=1, \lambda_{j}, s_{j}^{+}, s_{r}^{-} \leq 0
\end{aligned}
$$

\section{(b) Data}

A key issue in the implementation of DEA is the selection of inputs and outputs. A production unit will use a variety of resources to produce a unit of output of standard quality. Ideally, one would want to include all inputs and all outputs produced by the firm, but, in practice, the selection of inputs and outputs is restricted to those that can be measured with some accuracy. The selection of inputs and outputs is also restricted by the size of the sample of units observed. Boussofiane et al. (1991) suggest that the product of the number of inputs and outputs is a reasonable indicator of the minimum number of units needed to prevent a distortion of the efficiency measure.

A further issue with the selection of inputs and outputs refers to the underlying conceptualization of production in financial services. The issue here is to identify what it is that financial providers produce. Related literature applying DEA to the banking sector has identified two different approaches (Ferrier and Lovell, 1990). One approach stresses the intermediation function of financial providers between savers and borrowers. Within this approach, the output of the banking sector can be identified as, and measured by, the value of loans extended. A second approach, the production approach, identifies outputs with banking services and products measured by the value of accounts and transactions. In many respects, pension 
fund managers resemble banks, but of the two approaches mentioned the intermediation approach is inappropriate, especially given the dedicated nature of retirement savings accounts, the restricted liquidity of retirement savings, and the strict investment regulations. The production approach is preferable. Pension fund managers employ labour services, use capital equipment and buildings, and employ marketing services to attract and retain affiliates.

The analysis below focuses on two measures of output: total revenue and the number of contributors. Inputs are marketing and sales costs, office personnel and executive pay, and administration and computing costs. As discussed above, competition among pension fund managers makes market share heavily dependent upon non-price advantage, that is, marketing and sales force capacity. This is captured by the first input variable. The nature of the business requires administrative competence, with a significant information technology component. This explains the selection of the other two variables. ${ }^{15}$

\section{MEASURING THE TECHNICAL EFFICIENCY OF PENSION FUND MANAGERS}

\section{(a) The efficiency of pension fund managers over time}

Applying DEA to the data for pension fund managers for the period from 1982 to 1999 generates efficiency scores for each fund manager in the market in each year. The average efficiency scores for the market over the period are presented in figure 2 .

It will be useful to focus initially on the unweighted mean efficiency score generated using the CCR model. The time series shows three distinct phases. The first, running from 1982 to 1989 , is characterized by rising technical efficiency. This is consistent with rapid growth in contributors, enabling pension fund managers to exploit economies of size, to better utilize capital equipment and branch network, and to distribute the large setup

Falta o resto da frase costs across a more widely. At the end of the first year in 1982, pension fund managers could have provided the same services with 42.7 percent of the inputs, but, by 1989, efficiency rises to 78.5 percent, and inefficiency is down by almost two thirds. The second phase starts in 1990 and ends in 
Figure 2: Pension fund management market efficiency in Chile (1982-1999)

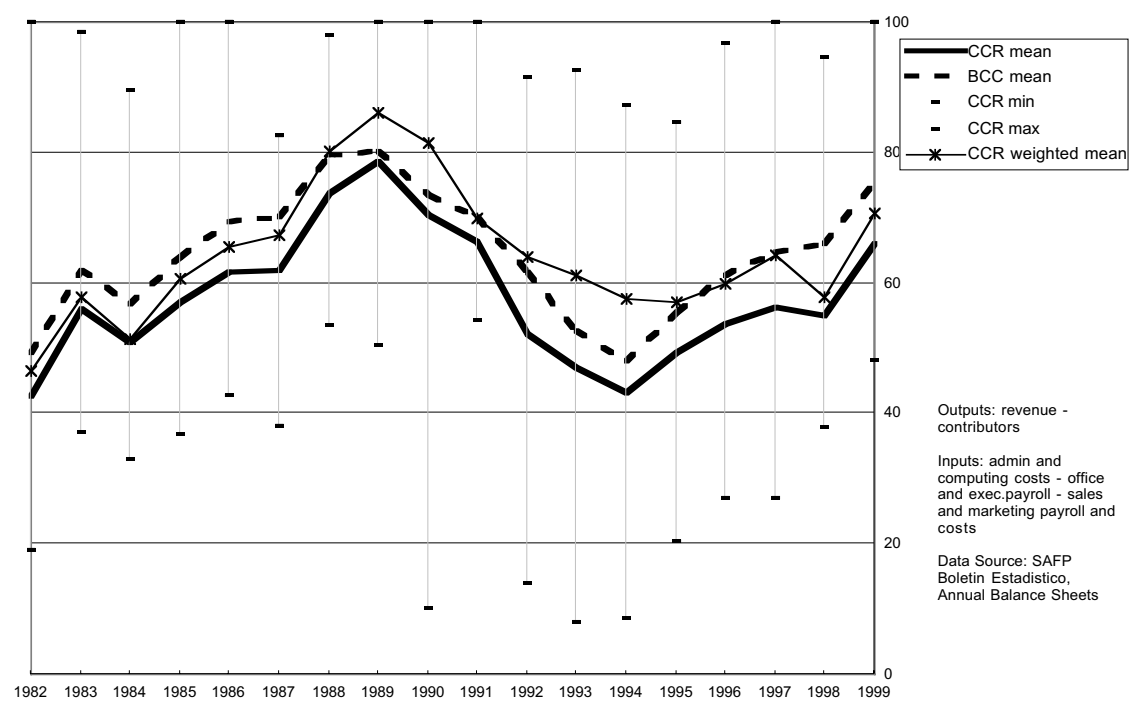

1994, and is characterized by a marked decline in technical efficiency. At the trough in 1994, the pension fund management market had returned to the inefficiency levels of 1982. An important contributory factor is the expansion in the number of fund managers in the market and the associated rise in sales and marketing costs. The third phase begins in 1995, with a steady improvement in market efficiency accelerating after 1998. This is consistent with a reduction in administration costs after 1994, and the precipitous fall in sales costs following changes in transfer regulations.

There is a wide range of annual efficiency scores, indicated by the distance between minimum and maximum scores, with very poor and very good performers. The dispersion in performance rises with the entry of new pension fund managers into the market in 1992. Comparison between the unweighted CCR mean score and a CCR mean weighted by the share of contributors provides some information on the relative technical efficiency of large and small pension fund managers over time. To the extent that larger fund managers have better efficiency scores, weighting the scores improves the average technical efficiency score. Interestingly, this applies only to a subset of years, roughly the period from 1987 to 1994. 
The BCC efficiency scores show a similar trend to that of the CCR scores, but generate consistently higher efficiency scores. This is because the efficiency scores obtained using the CCR model fail to distinguish between technical and scale inefficiency, but the efficiency scores generated by the BCC model incorporate scale effects. The mean BCC efficiency scores for the market as a whole range from a low of just below 50 percent in 1982 to a peak of 80.2 percent in 1989. At the end of the period under examination, the mean score suggests that the level of services could have been provided with a quarter fewer resources.

The examination of mean efficiency scores over time supports two important conclusions. Firstly, there are substantial potential efficiency gains in the pension fund management market. The efficiency scores indicate that the same services could have been provided with a fraction of the resources used by the pension fund managers. At the end of the period under examination, pension fund managers could have produced the same level of output with around 35 percent fewer resources. Secondly, whilst there is significant variation in technical efficiency over time for the market as a whole, there is no indication of a sustained upward trend in technical efficiency. Breaks in the trend of mean efficiency scores are consistent with regulatory changes, and the impact of new entrants on the structure of costs of pension fund managers, especially sales and marketing costs.

\section{(b) Pension fund managers efficiency and market strategies}

Table 2 shows, for selected years, CCR efficiency scores for individual pension fund managers ranked in descending order. There is some persistence in the ranking of pension fund managers over time. Habitat and Cuprum, for example, can be found among the top three rankings in all four years. Comparison of the top rankings over time suggests there are some advantages to early entrants. With a single exception, the fund managers operating in 1999 were in the market from the very beginning. At the other end of the spectrum, it appears that those pension fund managers with lower scores have a smaller chance of remaining in the market, especially when comparing 1994 and 1999. The consolidation in the market in the late 1990s appears to have eliminated the long tail of fund managers with low efficiency scores in 1994. 
There is evidence of two contrasting market strategies. On the one hand, there is a group of large fund managers who rely on maximising market share to exploit economies of size. These managers place less effort on selecting and retaining specific contributors, and therefore spend less per contributor on sales and marketing. As a result, they have a low ratio of con-

Table 2: Efficiency scores and market share of pension fund managers, 1984, 1989, 1994, 1999

\begin{tabular}{|c|c|c|c|c|c|c|c|}
\hline AFPs 1984 & CCR & $\mathrm{BCC}$ & Share & AFPs 1989 & CCR & $\mathrm{BCC}$ & Share \\
\hline Habitat 1984 & 89.46 & 89.75 & 7.0 & Habitat 1989 & 100 & 100 & 18.1 \\
\hline Cuprum 1984 & 87.81 & 92.44 & 1.7 & Provida 1989 & 100 & 100 & 28.9 \\
\hline Summa 1984 & 51.75 & 51.95 & 7.5 & Cuprum 1989 & 87.17 & 87.77 & 1.8 \\
\hline Santa Maria 1984 & 51.21 & 60.65 & 22.9 & Planvital 1989 & 86.55 & 88.47 & 2.0 \\
\hline Concordia 1984 & 50.50 & 52.27 & 1.5 & Proteccion 1989 & 83.35 & 85.06 & 1.1 \\
\hline Magister 1984 & 43.95 & 45.52 & 1.3 & Summa 1989 & 81.73 & 81.73 & 8.5 \\
\hline Provida 1984 & 43.84 & 92.60 & 32.3 & Futuro 1989 & 81.00 & 85.10 & 3.2 \\
\hline El Libertador 1984 & 42.06 & 45.59 & 1.3 & Union 1989 & 76.09 & 76.18 & 8.7 \\
\hline Alameda 1984 & 41.09 & 44.39 & 7.9 & El Libertador 1989 & 74.65 & 76.15 & 2.3 \\
\hline Invierta 1984 & 37.95 & 39.21 & 4.6 & Invierta 1989 & 73.10 & 74.17 & 2.9 \\
\hline Planvital 1984 & 34.16 & 35.65 & 2.8 & Santa Maria 1989 & 71.09 & 81.14 & 20.2 \\
\hline \multirow[t]{2}{*}{ San Cristobal 1984} & 32.84 & 32.97 & 8.9 & Concordia 1989 & 55.94 & 56.51 & 2.6 \\
\hline & & & & Magister 1989 & 50.31 & 51.59 & 2.1 \\
\hline AFPs 1994 & CCR & $\mathrm{BCC}$ & Share & AFPs 1999 & CCR & $\mathrm{BCC}$ & Share \\
\hline Cuprum 1994 & 87.13 & 90.56 & 5.2 & Cuprum 1999 & 100 & 100 & 10.7 \\
\hline Proteccion 1994 & 64.84 & 66.97 & 4.1 & Provida 1999 & 72.35 & 100 & 38.5 \\
\hline Habitat 1994 & 62.96 & 77.89 & 19.8 & Habitat 1999 & 67.38 & 89.19 & 23.1 \\
\hline Summa 1994 & 58.70 & 63.23 & 7.8 & Planvital 1999 & 63.36 & 63.45 & 2.7 \\
\hline Provida 1994 & 57.54 & 86.24 & 29.5 & SummaBans 1999 & 63.31 & 72.70 & 9.2 \\
\hline Santa Maria 1994 & 55.74 & 71.31 & 16.6 & Santa Maria 1999 & 59.38 & 74.91 & 13.4 \\
\hline Bansander 1994 & 53.89 & 54.26 & 2.0 & AportaFomenta 1999 & 53.85 & 55.05 & 0.6 \\
\hline Planvital 1994 & 45.99 & 46.34 & 2.6 & Magister 1999 & 48.17 & 48.79 & 1.6 \\
\hline El Libertador 1994 & 45.54 & 45.66 & 1.3 & & & & \\
\hline Magister 1994 & 44.61 & 44.92 & 1.5 & & & & \\
\hline Concordia 1994 & 41.41 & 41.92 & 0.2 & & & & \\
\hline Fomenta 1994 & 38.96 & 40.40 & 0.2 & & & & \\
\hline Union 1994 & 38.94 & 40.23 & 4.8 & & & & \\
\hline Futuro 1994 & 36.59 & 38.78 & 0.2 & & & & \\
\hline Banguardia 1994 & 34.82 & 36.39 & 0.6 & & & & \\
\hline Previpan 1994 & 24.99 & 28.32 & 0.3 & & & & \\
\hline Armoniza 1994 & 23.49 & 28.68 & 0.3 & & & & \\
\hline Qualitas 1994 & 23.04 & 25.44 & 0.2 & & & & \\
\hline Genera 1994 & 16.69 & 21.15 & 0.1 & & & & \\
\hline Valora 1994 & 8.590 & 14.39 & 0.1 & & & & \\
\hline
\end{tabular}

Authors' own calculations for efficiency scores, and Superintenencia de Administradoras de Fondos de Pensiones (several issues) for contributors data. 
tributors to affiliates. Theres is another group of fund managers who choose to remain relatively small and focus on attracting and retaining high earners. They have higher spending on sales and marketing per contributor, but enjoy a stable contributor base (high ratio of contributors to affiliates), as higher earners are less likely to have contributory gaps and are offered incentives to stay with their fund manager. The higher costs faced by the latter group can be absorbed by higher earnings-related fees and charges. This way, smaller fund managers with lower efficiency scores can survive and prosper in the market. Magister, which has remained in the market despite low efficiency scores through the selected years, is a good example. ${ }^{16}$ The market segmentation produced by these two different market strategies has showed a tendency to decline over time, as fewer smaller fund managers remain in business.

\section{(c) Determinants of pension fund managers technical efficiency}

The discussion above suggests the influence of different factors on the technical efficiency of pension fund managers. The extent to which fund managers are able to exploit size economies in the market is a key factor, but regulation, and the managers' response to the regulatory environment are also important. The impact of contrasting market strategies by larger and smaller fund managers is important here, as these have different implications for technical efficiency. The determinants of technical efficiency are investigated by regressing variables capturing market structure, regulation, and market segmentation, on efficiency scores. The dependent variable is the vector of CCR efficiency scores for the entire period. The independent variables include the market share of fund managers measured as the percentage of total contributors in a particular year (mkshare), which captures the influence of market structure. The impact of regulation is proxied by two variables, the ratio of contributors to affiliates (ratio), and a measure of sales spending per contributor (sales). As noted above, pension fund managers can absorb higher costs if they are able to select high earners, but at the cost of higher sales expenditure per contributor. Finally, a measure of revenue per contributor (revenue) is also included to attempt to control for the trend in these variables over time. ${ }^{17}$ The regression results are reported in table 3. 
Table 3. Regression results Dependent variable: CCR efficiency scores 1982-1999

\begin{tabular}{lcccrr}
\hline & Parameter & t-stat & Sig. & Mean & St. dev. \\
\hline Constant & 45.03 & 10.51 & 0.00 & & \\
\hline Mkshare & 0.52 & 4.18 & 0.00 & 7.56 & 0.09 \\
\hline Sales & -0.62 & -11.23 & 0.00 & 26.79 & 28.66 \\
\hline Ratio & 0.12 & 2.12 & 0.04 & 59.77 & 0.18 \\
\hline Revenue & 0.17 & 9.24 & 0.00 & 103.11 & 85.96 \\
\hline
\end{tabular}

Mean of LHS $=56.9 ; R^{2}=.648 ;$ Adj. $R^{2}=.410 ; N=238$

The estimated parameters indicate that higher market share is associated with higher efficiency scores, reflecting the impact of size economies on pension fund managers' costs. The parameters associated with the variables proxying responses to regulation have different signs. Higher sales spending per contributor is strongly associated with lower efficiency scores, but a higher ratio of contributors to affiliates has a positive effect on efficiency scores. These results suggest that larger pension fund managers, because they are able to take advantage of size economies, have higher efficiency scores and contribute to the technical efficiency of the market. On the other hand, relatively smaller pension fund managers who rely on segmenting the market and attracting high earners have a detrimental effect on market technical efficiency, except to the extent that they are able to generate fund manager-contributor attachment.

\section{CONCLUSION}

The paper has investigated the technical efficiency of the pension fund management market in Chile. Pension reform in Latin America has created pension fund management markets in nine countries so far. In the reformed pension systems in Latin America, pension fund managers are expected to compete to attract and retain affiliates, but are subject to extensive regulation. The efficiency of the new pension providers will be key to the success of the reforms, to their impact on the economies of the region, and to the well-being of pensioners.

We began by discussing standard indicators of performance in the market, and identifying key issues of efficiency, competition, and regulation. The indicators give a mixed picture of the performance of pension fund 
managers. Despite a significant variation in the number of managers pointing to the absence of significant barriers to entry and exit, and the rise in account transfers, it would appear that competition is limited. The issue is whether competition is limited by the presence of size economies, information asymmetries, or regulation. Examination of the trends in operational costs of pension fund managers shows no sustained downward trend, and changes in operational costs over time appear to be largely a response to regulatory environment. The regulation of fees enables a misalignment of fund managers' revenues and costs, and a segmentation in market strategies, where a group of fund managers maximises market share and size economies, while another group focuses on selecting high earners. The impact of segmentation on technical efficiency requires investigation.

This paper measured the technical efficiency of pension fund managers in Chile over time using Data Envelopment Analysis Techniques. The findings suggest that there are significant potential technical efficiency gains in the pension fund management market in Chile. There are important changes over time, but no continuous trend towards an improvement in technical efficiency. At the start of the reform, pension fund managers could have produced the same output with 40 percent of the resources utilized. Technical efficiency improved during the 1980s, but new entrants in the early 1990s, and the rise in sales and marketing costs associated with their entry, led to a decline in market efficiency. Regulations restricting transfers introduced in 1998 have been successful in scaling down sales and marketing costs and improving efficiency scores. At the end of the period, pension fund managers could have produced the same output with 65 percent of the resources utilized.

Comparison of efficiency scores of individual pension fund managers over time shows that market stayers have higher efficiency scores compared to market leavers, thus suggesting that competition works, albeit imperfectly, over time. At the same time, fund managers with low efficiency scores are able to survive in the market. Analysis of the determinants of technical efficiency shows that an increased market share contributes positively to technical efficiency. Sales and marketing costs, on the other hand, are detrimental. Two market strategies are viable in the market: larger pension fund managers can exploit economies of size, but smaller ones can fo- 
cus on attracting and retaining high earners. Inefficiency in the pension fund management market has strong adverse implications for future pension outcomes.

\section{NOTES}

1. Pension reform has been implemented in Chile (1981), Peru (1993), Argentina and Colombia (1994), Uruguay (1996), Bolivia and Mexico (1997), Costa Rica and El Salvador (1998). Similar reforms have been implemented in Poland, Hungary and Kazakhstan.

2. The reforms have established markets from scratch, as only Brazil had a significant pension fund management market before the recent reforms (Yermo, 2000).

3. See Margozzini (1995) for a description of the legal and regulatory framework.

4. The World Bank stated in its 1994 report that “... decentralized plans have more incentive to operate efficiently than centralized plans that have a monopoly in a compulsory system” (World Bank, 1994, p. 224). Mesa-Lago argues this statement is a myth (2002). The fragility of financial institutions in Latin America is a factor that explans the extent of regulation.

5. The restoration of democracy in 1990 enabled trade unions and regional bodies to set AFPs.

6. This reserve, or encaje, was initially 5 percent of the pension fund.

7. The general literature suggests that economies of scale are present in banking and other financial institutions. A recent survey of research in this area concluded that the average cost curve of banking institutions shows a flat U-shape (Berger, Hunter et al., 1993). Among US banks with over US \$1 billion in assets, average costs appear to be lowest, in the range of US\$ 2 to 10 billion. Mitchell (1996) studies the cost structure of different pension savings institutions, and finds significant economies of scale in pension fund provision. For employer sponsored pension plans in the USA, costs rise by 0.27 percent for every 1 percent rise in assets, and 0.8 percent for every 1 percent rise in contributors. Strictly, these are economies of size rather than economies of scale. In financial institutions, size differences normally involve more than a simple scale factor, and include output, as well as input, efficiency gains (Berger, Hunter et al., 1993).

8. Transfer fees are allowed by regulation, but have seldom been applied by pension fund managers.

9. See Valdés-Prieto (1992) for a discussion of the complexity of the information required, and Diamond (1993) for a more general discussion of market failure in the context of insurance markets.

10. Affiliates are those who have opened a retirement account at any time since 1981, while active contributors are those who make regular contributions to their accounts.

11. Reviewing trends in Chile, the 1994 World Bank report anticipated that the "entry of new AFPs in a competitive market may eventually lead to lower costs and fees" (World Bank, 1994, p.225). 
12. For the market as a whole, nearly 95 percent of fee income came from this source in 1995.

13. In December 1999, two pension fund managers charged fixed fees for withdrawals under the phased withdrawal and deferred life annuity retirement pensions. Two other fund managers charged variable fees on the retirement fund.

14. At the start of the reform in 1981, pension fund managers charged fixed and variable fees on pension fund balances. One effect of this was to dramatically reduce the pension fund of workers who, due to unemployment or inactivity, ceased to contribute regularly. Adverse public perception led to inactive contributors being exempted from fees. Most fees fall upon regular contributors. The main fee is charged as an additional contribution, which includes a disability and survivor insurance premium. This fee has fluctuated between 2.4 and 3 percent of earnings. In December 1999, for example, the average additional contribution was 2.4 percent and the insurance premium, was 0.65 percent. The net variable fee was therefore 1.75 percent of earnings.

15. The data used in the analysis below were extracted from the balance sheets of the pension fund managers reported annually to the regulator, and from published pension system information. (Superintendencia de Administradoras de Fondos de Pensiones, several issues).

16. Magister has benefited from a strong association with the teachers trade union, and Cuprum from a similar association with copper workers trade unions.

17. The ratio of contributors to affiliates, and sales spending, have a tendency to rise over time.

\section{REFERENCES}

ABUHADBA, M. (1994) “Aspectos organizacionales y competencia en el Sistema Previsional”. Mimeo. Santiago.

BANKER, R. D., CHARNES, A., COOPER, W. W. (1984) "Some models for estimating technical and scale inefficiencies”. In: Data Envelopment Analysis, Management Science, 30, 10781092 .

BARRIENTOS, A. (1998) Pension Reform in Latin America. Aldershot: Ashgate.

(1999) “The emerging pension fund management market in Latin America”. Journal of Pensions Management, 5 (1), 60-68.

BERGER, A. N., HUNTER, W. C., TIMME, S. G. (1993) “The efficiency of financial institutions”. Journal of Banking and Finance, 17, 221-249.

BERTÍN, H. (1997) “Tres años del régimen de capitalización individual: rentabilidad, eficiencia y solvencia de las AFJP”. Serie Estudios Especiales 11. Buenos Aires: Superintendencia de Administradoras de Fondos de Jubilaciones y Pensiones.

BOUSSOFIANE, A., DYSON, R. G. (1991) “Applied Data Envelopment Analysis. European Journal of Operational Research, 52, 1-15.

CHARNES, A., COOPER, W. W., RHODES, E. (1978) "Measuring the efficiency of decision making units". European Journal of Operational Research, 2 (6), 429-444. 
DIAMOND, P. (1993) "Privatization of social security: lessons from Chile". Working Paper 4.510: NBER.

EDWARDS, S. (1996) “The Chilean pension reform: a pioneering program”. Working Paper 5.811, Cambridge MA: National Bureau of Economic Research.

FERRIER, G. D., LOVELL, C. A. (1990) "Measuring cost efficiency in banking: econometric and linear programming evidence”. Journal of Econometrics, 46, 229-245.

FIELDS, J. A., MURPHY, N. B. (1989) "An analysis of efficiency in the delivery of financial services: the case of UK insurance agencies”. Journal of Financial Services Research, 2, 343356.

, TIRTIROGLOU, D. (1993) “An international comparison of scale economies in banking”. Journal of Financial Services Research, 7, 111-125.

JAMES, E., FERRIER, G., SMALHOUT, J., VITTAS, D. (1998) “Mutual Funds and Institutional Investments: what is the most effective way to set up individual accounts in a social security system?”. Mimeo. Washington DC: The World Bank.

— SMALHOUT, J., VITTAS, D. (2001) “Administrative costs and the organization of individual account systems: a comparative perspective”. In: R. Holzmann, J. E. Stiglitz (eds.), New ideas about Old Age Security. Towards Sustainable Pension Systems in the $21^{\text {st }}$ Century. Washington DC: The World Bank, 254-307.

— VITTAS, D. (1996) "Mandatory saving schemes: are they the answer to the old age security problem?”. In: Z. Bodie, O. S. Mitchell, J. A. Turner (eds.), Securing Employerbased Pensions. An International Perspective. Philadelphia: University of Pennsylvania Press, 151-192.

MARGOZZINI, F. (1995) “The Industria de AFP”. In: S. Baeza, F. Margozzini (eds.), Quince años después: una mirada al sistema privado de pensiones. Santiago: Centro de Estudios Públicos, 99-130.

MESA-LAGO, C. (2002) "Myth and Reality of Pension Reform: the Latin American Evidence". World Development, 30 (8), 1309-1321.

--, C., BERTRANOU, F. (1998) Manual de Economía de la Seguridad Social. Montevideo: Centro Latinoamericano de Economía Humana.

MIRANDA, E. (1994) "Evidencia de economías de escala en las administradoras de fondos de pensiones. Estudios de Administración, 1 (1), 45-79.

MITCHELL, O. S. (1996) “Administrative costs in public and private retirement systems". Working Paper 5.734. Cambridge, MA: National Bureau of Economic Research.

NASSER KATIB, M., MATTHEWS, K. (1999) “A Nonparametric approach to efficiency measurement in the Malaysian banking sector”. Discussion Papers in Economics 99: 113. Cardiff: Cardiff Business School.

PAREDES, R. (2000) “Gastos de Comercialización de las Administradoras de Fondos de PenA. d. A. d. siones (AFP)”. In: A. d. A. d. F. d. Pensiones (ed.), AFP Chile: logros y desafíos. Santiago: F. d.?? Asociación de Administradoras de Fondos de Pensiones, 329-367.

QUEISSER, M. (1998a) "Regulation and supervision of pension funds: principles and practices”. International Social Security Review, 51. (2/98), 39-55. 
(1998b) “The second-generation pension reforms in Latin America”. Working Paper AWP 5.4, Paris: OECD.

SCHMIDT-HEBBEL, K. (1999) "Latin America's Pension Revolution: a review of approaches and experience". Mimeo. Washington DC: Central Bank of Chile.

SINHA, T., MARTÍNEZ, F., BARRIOS-MUÑOZ, C. (1998) "Performance of publicly mandated private pension funds in Mexico: simulations with transaction costs". Mimeo. Mexico DF: Instituto Tecnológico Autónomo de Mexico.

SUPERINTENDENCIA DE ADMINISTRADORAS DE FONDOS DE JUBILACIONES Y PENSIONES (1996) Reformas a los sistemas de pensiones. Argentina, Chile, Peru. Buenos Aires: SAFJP. (several issues) Boletín Estadístico (several issues).

VALDÉS-PRIETO, S. (1992) “Selección de AFP y regulación de la información. Working Paper 140. Santiago: Instituto de Economía, Pontificia Universidad Católica de Chile.

VITTAS, D. (1998) “Regulatory controversies of private pension funds". Mimeo. Washington DC: The World Bank.

WORLD BANK (1994) Averting the Old Age Crisis: policies to protect the old and promote growth. Londres: Oxford University Press.

YERMO, J. (2000) "Institutional investors in Latin America: recent trends and regulatory challenges. In: OECD (ed.), Institutional Investors in Latin America. Paris: OECD, 23-120. 